\title{
CONTENT OF CHLOROPLASTS IN THE LEAVES OF PLANTS SPRING DURUM WHEAT IN DEPENDING OF MINERAL NUTRITION
}

I. O. SHUTIY postgraduate*

\author{
S. M. KALENSKA, Doctor of Agricultural Sciences, professor \\ National University of Life and Environmental sciences of Ukraine
}

E-mail:shutij@ukr.net

\begin{abstract}
Shown results of the three-years study (2012-2014 gg.). For determination dynamics of formation pigments of photosynthesis in spring durum wheat plants with actions of different fertilizing options. Was established a significant impact of studied technology elements on chlorophyll content in the leaves of plants. It is established that using of foliar feeding on background of main fertilizer has a positive impact on productivity and quality of the studied varieties. Was find out the role of plant nutrition system that enables to control formation of photosynthetic pigments in leaves of spring durum wheat plants. Was established, that optimization of fertilizing mode provides a complete disclosure of resource potential of plants thereby increasing yield.

Keywords: spring durum wheat, pigments, photosynthesis, fertilizing system, extranutrition, productivity
\end{abstract}

Increasing of grain production in the world is a pressing problem today [1]. Needing to provide people with food, animal - with quality feed, industry - with raw materials grows constantly, exposing new challenges to agricultural production [2].

Cereals developing by spring type concede for winter grain in yields, but they have a significant advantage on grain quality. Actually because of high grain quality spring forms received considerable attention [3]. Durum spring wheat is characterized by a special chemical composition that can be used for food production, which cannot be produced from other grain crops without losing quality $[4,5]$. Grain of durum spring wheat is valuable grain crop, which in food value and scale of production should take high place. Usually grain of durum wheat (Triticum durum Desf.) use for making pasta, cereals, and can act as a bread improver [6].

Definition of pigments accumulation in the leaves of plants is essential, insofar as

\footnotetext{
* Supervisor - Doctor of Agricultural Sciences, professor, corresponding member of NAAS of Ukraine S. M. Kalenska
} 
their content affects on rate of photosynthesis and others physiological processes. The study aimed to establish features of accumulation and metabolism of photosynthesis pigments, especially system of formation pigment mechanism in leaf in ontogeny have a particular importance in assessing impact of technological elements on plant productivity [5].

One of the key and influential factors that affect on yield and quality are the nutrients, form of their compounds and methods of using. Higher productivity and improving of grain quality depend from mineral nutrition due to increasing in the soil available elements. Fertilizers contribute in formation of bigger area and effectiveness of assimilation system, growth and dry matter accumulation, increasing productivity of photosynthesis, increasing of plant productivity [7].

New intensive type varieties with high yield potential needs depth study of the all elements of photosynthetic activity at different levels of assimilation system - from cenosis to the cells, chloroplasts.

Photosynthesis associated with physiological functions of plants, especially with the growth and development parts of plants $[4,8]$. In ontogenesis of wheat with impact of endogenous factors happens permanent correction which realized in functions of growth and development of phytomer elements and provides productivity.

During photosynthesis occurs formation of organic matter. For photosynthesis passing in plant cells should exist pigmets - chlorophylls and carotenoids [3,7]. Content of pigmets in structure of the photosynthetic apparatus of plants influences on productivity and intensity of photosynthesis, and hence the yield

Pigment complex of plant organism is very sensitive to changes in environmental conditions $[2,5,8]$, that's why it should attributed to criteria's that determine degree of plants adaptation to natural and anthropogenic environmental factors. Detection of changes of Pigment content in the leaf of spring durum wheat will enable to manage process of crops development, formation of organic matter by plants and their grain productivity. [8]

The aim of the study was to establish effect of different varietal characteristics and different options of mineral nutrition on pigments content in the leaves of plants, 
because their content affects on the intensity of physiological processes, especially on passing photo-synthesis processes and formation of grain productivity through the use of macro and microelements for getting high-quality grain and increasing productivity at the same time.

Materials and methods of research. Research was conducted in 2014-2016's on stationary field experiment of Plant growing department NULES of Ukraine PC "Agronomic Research Station" (v. Psenychne, Kyiv region). The scheme of experiment included determination the impact of main fertilizer and foliar feeding with nitrogen and micronutrients on yield and grain quality of spring durum wheat. Soil of the research area - typical black soil, medium loamy. The humus content in the topsoil 4,3-4,5\%, availability of soil nitrogen - average, moving phosphorus - above average, exchangeable potassium - average. Preceded - soybean. Square of elementary area - 60 $\mathrm{m} 2$, of counted area $-30 \mathrm{~m} 2$, quadruple repetition of the experiment, the systematic placement options (Table 1).

\section{Scheme of experiment}

\begin{tabular}{|c|c|c|c|c|c|c|c|}
\hline \multirow{3}{*}{$\begin{array}{l}\text { Variety } \\
\text { factorA }\end{array}$} & \multicolumn{7}{|c|}{$\begin{array}{l}\text { Systemoffertilizing, кг/га д.p. } \\
\text { factor } B\end{array}$} \\
\hline & \multirow{2}{*}{$\begin{array}{c}\text { Short } \\
\text { marking of } \\
\text { variants } 1\end{array}$} & \multicolumn{3}{|c|}{ Main fertilizing } & \multicolumn{3}{|c|}{ Extranutrition $^{2}$} \\
\hline & & $\mathrm{P}_{2} \mathrm{O}_{5}$ & $\mathrm{~K}_{2} \mathrm{O}$ & $\mathrm{N}$ & IV & VI & $X$ \\
\hline \multirow{3}{*}{ Kharkivska - 27(st) } & $\mathrm{B} 1(\mathrm{c} 1)$ & \multicolumn{6}{|c|}{ Without fertilizer ( control 1) } \\
\hline & $\mathrm{B} 2$ & 75 & 75 & 50 & - & - & - \\
\hline & $\mathrm{B} 3(\mathrm{c} 2)$ & 75 & 75 & 75 & - & - & - \\
\hline \multirow{2}{*}{ Kharkivska - 41} & B4 & 75 & 75 & 100 & - & - & - \\
\hline & B5 & 75 & 75 & 75 & $\mathrm{~N} 12,5$ & $\mathrm{~N} 12,5$ & - \\
\hline \multirow{3}{*}{ Isolda } & B6 & 75 & 75 & 75 & $\begin{array}{l}\text { N12.5+RZ, } \\
\text { RM. }\end{array}$ & $\begin{array}{l}\text { N12,5+R } \\
\text { P, RM. }\end{array}$ & - \\
\hline & B7 & 75 & 75 & 75 & $\mathrm{~N} 8,3$ & $\mathrm{~N} 8,3$ & $\mathrm{~N} 8,3$ \\
\hline & B8 & 75 & 75 & 75 & $\begin{array}{l}\text { N8.3+ } \\
\text { RZ,RM. }\end{array}$ & $\begin{array}{c}\text { N8.3+ } \\
\text { RP, RM }\end{array}$ & $\mathrm{N} 8.3+\mathrm{RZ}$ \\
\hline
\end{tabular}

Remarks: ${ }^{1} \mathrm{c} 1$ - control 1 (without fertilizer); c2 -control 2 (Recommendedsystemoffertilizer);R.Z. - Rostokzernovyi ; R.M. - Rostokmacro; R.P. - Rostokplodonoshennya; N - nitrogen

Extra nutrition was conducted in accordance with scheme of the experiment with using different by composition of fertilizers Rostock: Rostock zernovyi - application rate 2.51 / ha; Rostock macro - 11 / ha and Rostock plodonoshennya- 2.51 / ha. 
Phosphate and potash fertilizers was used in the form of granulated superphosphate and potassium salts application according to the scheme of experiment during primary tillage, nitrogen fertilizers -at the spring presowing cultivation. In foliar application by the stages of organogenesis - urea and micro fertilizers Rostock .

Micro fertilizer "ROSTOK" contains macro- and microelements on chelate base, used for pre-treatment of seeds and foliar feeding of plants and in fertigation. As you know, for normal plant development requires not only a macro elements and a micro, the most important micronutrients for grain crops is $\mathrm{Cu}, \mathrm{MgO}, \mathrm{Fe}, \mathrm{Zn}$ contained in fertilizers "Rostok" Zernovyi and Macro.

Results of research. Analysis of the impact of studied agronomic factors shows that more changes of pigment content in the leaves of plants was with different amounts of fertilizers. This pattern has been noted in all phases of development, in which conducted the definition. Thus, in the phase of flowering chlorophyll concentration averaged for three years of research for the actions of factor A (variety) ranged from 3.9 to $5.7 \%$, then the action of factor B (fertilization system) - from 11.7 to $24,5 \%$.

The maximum content of photosynthetic pigments in the leaves of spring durum wheat average for three years of research was in earing phase (Table. 2). A marked reduction in the concentration of all groups of pigments from earing phase to flowering phase and milky ripeness was in control variants, because fertilizers provides a longer duration of physiological processes of photosynthesis.

Reduction of photosynthetic pigments in the leaves of spring durum wheat at flowering phase is a natural process, when there is loss of water, the granules decay on chloroplasts and as result - their destruction.

All researched variants of fertilizing provided a significant increasing of chlorophyll $a$ in the leaves in compare with control variant. The most effective was a complex feeding by nitrogen and fertilizers "Rostokt" Zernovyi and Macro.

The content of chlorophyll in the leaves in average for three years of research was 2,14-2,75 $\mathrm{mg} / \mathrm{g}$ at earing phase, 2,24-2,85 mg / $\mathrm{g}$ - at flowering phase and 2,28-2, 89 $\mathrm{mg} / \mathrm{g}$ - at phase of milky ripeness. 
2. Content of chlorophyll $b$ in leaves of spring durum wheat plants for various mineral nutrition (average for 2012-2014.), $\mathrm{mg} / \mathrm{g}$

\begin{tabular}{|c|c|c|c|c|c|}
\hline \multirow[b]{2}{*}{$\begin{array}{l}\text { Phase of growth } \\
\text { and development }\end{array}$} & \multirow[b]{2}{*}{$\begin{array}{l}\text { Variant of } \\
\text { fertilizing }\end{array}$} & \multicolumn{4}{|c|}{ Variety } \\
\hline & & Kharkivska 27 & Kharkivska 41 & Jizel & Isolda \\
\hline \multirow{8}{*}{ Earing } & B1 & 2,73 & 2,97 & 2,67 & 2,9 \\
\hline & B2 & 3,59 & 3,69 & 3,71 & 3,86 \\
\hline & B3 & 3,61 & 3,72 & 3,84 & 3,96 \\
\hline & B4 & 3,78 & 3,75 & 3,99 & 3,98 \\
\hline & B5 & 3,85 & 3,96 & 4,01 & 4,00 \\
\hline & B6 & 3,88 & 4,11 & 4,05 & 4,03 \\
\hline & B7 & 3,93 & 3,98 & 4,07 & 4,06 \\
\hline & B8 & 3,97 & 4,08 & 4,15 & 4,07 \\
\hline \multirow{8}{*}{ Flowering } & B1 & 2,59 & 2,83 & 2,53 & 2,76 \\
\hline & B2 & 3,46 & 3,56 & 3,58 & 3,73 \\
\hline & B3 & 3,52 & 3,63 & 3,75 & 3,87 \\
\hline & B4 & 3,67 & 3,64 & 3,88 & 3,87 \\
\hline & B5 & 3,73 & 3,84 & 3,89 & 3,88 \\
\hline & B6 & 3,78 & 4,01 & 3,95 & 3,93 \\
\hline & B7 & 3,83 & 3,88 & 3,97 & 3,96 \\
\hline & B8 & 3,87 & 3,98 & 4,05 & 3,97 \\
\hline \multirow{8}{*}{$\begin{array}{c}\text { Milky- } \\
\text { waxripeness }\end{array}$} & B1 & 2,39 & 2,63 & 2,33 & 2,56 \\
\hline & B2 & 3,25 & 3,35 & 3,37 & 3,52 \\
\hline & B3 & 3,34 & 3,45 & 3,57 & 3,69 \\
\hline & B4 & 3,48 & 3,45 & 3,69 & 3,68 \\
\hline & B5 & 3,55 & 3,66 & 3,71 & 3,7 \\
\hline & B6 & 3,6 & 3,83 & 3,77 & 3,75 \\
\hline & B7 & 3,64 & 3,69 & 3,78 & 3,77 \\
\hline & B8 & 3,68 & 3,79 & 3,86 & 3,78 \\
\hline \multicolumn{3}{|c|}{$\begin{array}{l}S D_{0.5} \text { for factor «variety» } \\
L S D_{0.5} \text { for factor «fertilizing» }\end{array}$} & \multicolumn{3}{|c|}{$\begin{array}{l}0,11 \\
0,42\end{array}$} \\
\hline
\end{tabular}

Regarding amount of chlorophyll $b$ in leaves pattern was similar. The content of chlorophyll in the leaves in average for three years of research was $1,14-1,48 \mathrm{mg} / \mathrm{g}$ at the earing phase,18-1,52 $\mathrm{mg} / \mathrm{g}$ - at flowering phase and 1,20-1, $53 \mathrm{mg} / \mathrm{g}$ - at the phase of milky ripeness.

Yields of spring durum wheat significantly changed by years of research, in depending of different doses of fertilizer and were noticed varietal reaction of plants for using different doses of macro- and micronutrients - from 1.43 to $5.20 \mathrm{t} / \mathrm{ha}$ in the context of all studied factors (Table. 3). 


\section{Yieldsofspringdurumwheat, $\mathrm{t} / \mathrm{ha}$}

\begin{tabular}{|c|c|c|c|c|c|c|c|c|}
\hline \multirow[b]{2}{*}{$\begin{array}{c}\text { Optionofex } \\
\text { periment }\end{array}$} & \multicolumn{4}{|c|}{ varietyKharkivska -27 } & \multicolumn{4}{|c|}{ varietyKharkivska -41 } \\
\hline &  & $\stackrel{m}{\stackrel{i}{\sigma}}$ & $\stackrel{\nabla}{\stackrel{\nu}{d}}$ & 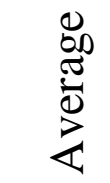 & $\stackrel{\text { ㄱ }}{\circ}$ & $\stackrel{m}{\stackrel{n}{2}}$ & $\stackrel{\nabla}{\stackrel{\nu}{\nu}}$ & 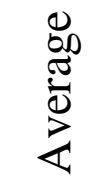 \\
\hline $\mathrm{B} 1(\mathrm{c} 1)$ & 1,68 & 1,43 & 1,61 & 1,61 & 2,09 & 1,87 & 2,18 & 2,05 \\
\hline B2 & 2,76 & 2,28 & 2,67 & 2,67 & 2,95 & 2,17 & 3,19 & 2,77 \\
\hline B3(c2) & 3,25 & 2,96 & 3,19 & 3,19 & 3,39 & 2,73 & 3,72 & 3,28 \\
\hline B4 & 3,34 & 3,27 & 3,36 & 3,36 & 3,54 & 2,85 & 3,90 & 3,43 \\
\hline B5 & 3,76 & 3,42 & 3,63 & 3,63 & 4,28 & 3,69 & 4,16 & 4,04 \\
\hline B6 & 3,98 & 3,49 & 3,84 & 3,84 & 4,42 & 3,85 & 4,30 & 4,19 \\
\hline B7 & 3,57 & 3,50 & 3,56 & 3,56 & 3,93 & 3,76 & 4,48 & 4,06 \\
\hline B8 & 3,71 & 3,66 & 3,71 & 3,71 & 4,05 & 3,81 & 4,61 & 4,16 \\
\hline \multicolumn{5}{|c|}{ varietyJizel } & \multicolumn{4}{|c|}{ varietyIsolda } \\
\hline $\mathrm{B} 1(\mathrm{c} 1)$ & 2,13 & 1,83 & 2,50 & 2,15 & 1,98 & 1,59 & 2,37 & 1,98 \\
\hline B2 & 3,48 & 3,53 & 3,75 & 3,59 & 3,43 & 2,62 & 3,37 & 3,14 \\
\hline $\mathrm{B} 3(\mathrm{c} 2)$ & 4,19 & 4,21 & 4,27 & 4,22 & 3,89 & 3,31 & 3,73 & 3,64 \\
\hline $\mathrm{B} 4$ & 4,01 & 4,19 & 4,02 & 4,07 & 3,91 & 3,31 & 3,93 & 3,72 \\
\hline B5 & 4,62 & 4,65 & 5,10 & 4,79 & 4,73 & 3,46 & 4,73 & 4,30 \\
\hline B6 & 4,72 & 4,79 & 5,20 & 4,90 & 4,82 & 3,85 & 4,95 & 4,54 \\
\hline B7 & 4,84 & 4,73 & 4,96 & 4,84 & 4,34 & 3,94 & 4,45 & 4,24 \\
\hline B8 & 4,93 & 4,82 & 5,11 & 4,95 & 4,42 & 4,05 & 4,59 & 4,35 \\
\hline \multicolumn{5}{|c|}{$\begin{array}{l}L S D_{0.5} \text { for factor } \text { «variety» } \\
L S D_{05} \text { for factor } \text { «ertilizing } \\
L S D_{05} \text { for factor } \text { "weatherconditions» }\end{array}$} & & & & \\
\hline
\end{tabular}

The effectiveness of fertilizer is determined by complex of abiotic and technological factors. Efficiency of extra nutrition was significantly increased with using of micronutrients complex "Rostok."

Established feasibility of combination nitrogen fertilizer and micronutrient Rostock, which are with much smaller doses had effect, equivalent to mineral nitrogen forms of fertilizers. Thus, in variety Kharkivska 27 fertilizer application had a positive influence on yield formation which varied depending of fertilization variant from 2.67 to $3.84 \mathrm{t} /$ ha, yield in the control variant (without fertilizers) was 1,61t / ha. Using of nitrogen fertilizer in extra feeding at the stages of organogenesis boosted the yield from 0.37 to 0.66 tonnes / ha compares with application the same doses of fertilizers in presowing cultivation. 
A similar pattern was observed in variety Kharkivska 41, yield was in the range from 2.77 to $4.19 \mathrm{t} / \mathrm{ha}$, which 0, 72-2, $14 \mathrm{t} /$ ha higher than at the control (without fertilizer). The highest yield was obtained at the variant B6, which amounted $4.19 \mathrm{t} /$ ha.

In variety of durum wheat Isolda fertilizers and extra nutrition by mikrofertilizer Rostock had a positive impact on productivity Formation. Yield indicators was changed in depending of fertilizer dose from 3.14 to 4.35 tonnes / ha, the yield at the control variant $-1,98 \mathrm{t} / \mathrm{ha}$.

The highest yield among the studied varieties was received at variety Jizel in variant B8 and was $4.95 \mathrm{t} / \mathrm{ha}$, what is on 2, $86 \mathrm{t} / \mathrm{ha}$ more compared with the control. Thus, based on the obtained results we can state that foliar feeding by water-soluble fertilizer with micro elements have effect on yield increasing of spring durum wheat

So, foliar feedings - a significant reserve for full disclosure of resource potential of grain productivity spring durum wheat of new intensive type varieties - Isolda and Jizel.

Conclusions. Fertilizing system of spring durum wheat generally provides a significant increasing of content photosynthetic pigments in the leaves. Optimization of feeding mode provides a more complete disclosure of plants resource potential thereby increasing yield. Established, that new high-yield varieties - Jisel and Isolda reveal their grain potential in variants with extra nutrition on the organogenesis stages at background of the main fertilizer $\mathrm{N}_{75} \mathrm{P}_{75} \mathrm{~K}_{75}$.

\section{References}

1. Antal, T. V. (2010). Performance of spring durum wheat in depending of technology elements at the Right-bank Steppes of Ukraine: Abstr. sum.cand. of agricultural Science.,NULES, P. 22.

2. Kalenska, S. M. Plaksa V. M. (2009) Effect of seeding rate, mineral and water soluble fertilizers on growth and development of spring triticale / Scientific Journal NULES of Ukraine.P. 123-129.

3. Rojkov A. O., Puzik V. K., Kalenska S. M., Puzik L.M. Bobro M. A., Chugrin O. V. Antal T. V, (2015). Management Performance by seeds of spring durum wheat at the Left-bank and Northern Foreststeppe of Ukraine /: Maidan. P 432.

4. Committee of World Food Security. [Electronic resource]. - Access mode: www.yara.ua/crop-nutrition/crops/wheat/key-facts/world-wheat-production

5. Franzen, D.W.(2014)Fetilizing hard red spring Wheat and durum / NDSU extension service, 8 p.: https://www.ag.ndsu.edu/pubs/plantsci/soilfert/ sf712.pdf

6. Robertson, E. I. (1995). Significant Changes in Cell and Chloroplast Development in Young Wheat leawes (Triticumaestivum w Hereward) Grown in 
Elevated CO2 / Plant Physiol - P. 63-71.

7. Sims, D. A.(2002). Relationships between leaf pigment content and spectral reflectance across a wide range of species. Leaf structures and developmental stages / RemoteSinsing of Environment, - P. 337-354.

8. Thomas H. (1997).Chlorophyll: a symptom and a regulator of plastid development. NewPhytologist, - P. 163-181

\section{СОДЕРЖАНИЕ ХЛОРОПЛАСТОВ В ЛИСТЬЯХ РАСТЕНИЙ ПШЕНИЦЫ ТВЕРДОЙ ЯРОВОЙ В ЗАВИСИМОСТИ ОТ МИНЕРАЛЬНОГО ПИТАНИЯ}

\section{А. И. Шутый, С. М. Каленская}

Аннотация. Представлены результаты трехлетних исследований (2012 2014 г2.) По определению динамики формирования пигмента фотосинтеза в растениях пшениць твердой яровой за действия различных вариантов удобрения. Установлено значительное влияние исследуемых элементов технологии на содержание хлорофиллов в листьях растений.Установлено, что применение внекорневой подкормки на фоне основного удобрения положительно влияет на производительность и качество исследуемых сортов. Обосновано роль системь питания растений, которая дает возможность управлять формированием пигментов фотосинтеза в листьях растений пшеницы твердой яровой. Оптимизировано режим питания которыйобеспечивает более полное раскрытие ресурсного потенциала растений за счет чего повышается урожайность.

Ключевые слова: пшенииа твердая яровая, пигменты, фотосинтез, система удобрения, подкормки, производительность

\section{ВМІСТ ХЛОРОПЛАСТІВ У ЛИСТКАХ РОСЛИН ПШЕНИЦІ ТВЕРДОЇ ЯРОЇ ЗАЛЕЖНО ВІД МІНЕРАЛЬНОГО ЖИВЛЕННЯ О. І. Шутий, С. М. Каленська}

Анотація. Представлені результати трирічних досліджень (2012 - 2014 рр.) щодо визначення динаміки формування пітментів фотосинтезу в рослинах пшенииі твердої ярої за дії різних варіантів удобрення.. Встановлено значний вплив досліджуваних елементів технології на вміст хлорофілів у листках рослин. Встановлено, щзо застосування позакореневого підживлення на фоні основного удобрення має позитивний вплив на продуктивність та якість досліджуваних сортів. Обгрунтовано роль системи живлення рослин, яка дає можливість управляти формуванням пігментів фотосинтезу у листках рослин пшениці твердої ярої. Встановлено, що оптимізація режиму живлення забезпечує більш повне розкриття ресурсного потениіалу рослин за рахунок чого зростає врожайність.

Ключові слова: пшениия тверда яра, пігменти, фотосинтез, система удобрення, підживлення, продуктивність 